\title{
A Retrospective Study of the Culture and Sensitivity Pattern of Urinary Tract Infection Causing Organisms at RIMS Teaching Hospital, Raichur, India
}

\author{
R. Venkatesh Naik*, Basavaraj V. Peerapur and P. Sandhya \\ Department of Microbiology, RIMS, Raichur, Karnataka, India \\ *Corresponding author
}

\begin{tabular}{|l|}
\hline Ke y w o r d s \\
$\begin{array}{l}\text { Urinary tract } \\
\text { infections, E.coli, } \\
\text { Antimicrobial } \\
\text { resistance. }\end{array}$ \\
\hline Article Info \\
\hline $\begin{array}{l}\text { Accepted: } \\
\text { 14 September } 2017 \\
\text { Available Online: } \\
\text { 10 October } 2017\end{array}$ \\
\hline
\end{tabular}

\section{Introduction}

Urinary tract infections (UTIs) are one of the most common bacterial infections in humans both in the community and hospital setting. ${ }^{[1-}$ 3] UTI remains second most common infectious disease and approximately about 150 million people were diagnosed with UTI each year. ${ }^{[4]}$ UTI can be caused by different microorganisms including bacteria, protozoa, parasites, fungi and viruses are the major causative organisms. Among these bacteria account for more than $95 \%$ of UTI cases. ${ }^{[5]}$ $E$. coli is the most common isolate 
responsible for UTI. ${ }^{[6-9]}$ Other important pathogens are Klebsiella pneumoniae, Pseudomonas aeruginosa and Staphylococcus aureus. ${ }^{[10,11]}$ Distribution of uropathogens and their susceptibility to antibiotics is variable regionally ${ }^{[7,12]}$, so it becomes necessary to have a knowledge of distribution of uropathogens and their susceptibility to antibiotics in a particular setting. Antimicrobial resistance is a growing problem and a cause of major concern in many countries. ${ }^{[13]}$ This study is aimed to determine the distribution of bacterial uropathogens and their susceptibility to antimicrobials in patients who attended outpatient and inpatient from various departments of RIMS, Teaching Hospital, RAICHUR, Karnataka from September 2014 to April 2016.

\section{Materials and Methods}

This was a retrospective study conducted at RIMS, Teaching Hospital, Central Laboratory Microbiology Department, RAICHUR, Karnataka. The data of all cases with urine culture positive reports were analysed from Sep 2014 to April 2016. Over the course of study, total of 351 urine samples were collected. Out of those 351 successful samples 176 females and 175 males and were in the age group of 1 to above 60 years old. There were higher numbers of samples collected from the extreme of ages 1-9 years and above 60 years (Table 1 ).

\section{Collection of urine specimen}

The specimens were collected into sterilized, wide necked, leak proof, plastic universal containers. Clean-voided mid-stream urine specimens were collected. Each of the study participant was instructed on the mode of collection of the mid-stream urine that was during forceful urination after the first $10-20$ $\mathrm{ml}$ has been voided. ${ }^{[14]}$

\section{Sample preparation and microscopy}

The collected urine sample was prepared for microscopy according to standard method. The urine samples were mixed and aliquots centrifuged at $5000 \mathrm{rpm}$ for $5 \mathrm{~min}$. The deposits were examined using both $10 \mathrm{X}$ and $40 \mathrm{X}$ objectives. Samples with $\geq 6$ white blood cells/mm were regarded as pyuric. ${ }^{[15]}$

\section{Media preparation}

The media used were Blood Agar (BA), Nutrient Agar (NA) and Cysteine Lactose Electrolyte Deficient (CLED) Agar were prepared according to the manufacturer's instructions.

\section{Sample culturing}

The collected urine samples were processed for culture and report according to standard method procedure and protocol. For the visual examination and calibrated Loop Streak method for urine culture performed $1 \mu$ wire loop was sterilized and dipped of into urine sample. The loop was then streaked on the plate of Cysteine Lactose Electrolyte Deficient (CLED) Agar. The plates were incubated over night at $37^{\circ} \mathrm{C}$ for 24 to 48 hours. Following the appearance growth wellisolated bacterial colonies were processed for antibiotic sensitivity and biochemical tests. ${ }^{[16]}$

\section{Identification of microorganisms}

All bacterial isolates were characterized on the basis of colony morphology, Gram staining, Catalase test, Coagulase test, and oxidase tests. From the results of preliminary identification test the gram negative rods were subjected to the following routine biochemical tests such as mannitol motility test, indole production, urease production, citrate utilization test and Triple sugar iron reaction. ${ }^{[17]}$ 


\section{Sensitivity test}

All isolated organisms were tested against various antibiotics in vitro, antibiotic susceptibility was tested in laboratory by disc diffusion method ${ }^{[18]}$ on Muller Hinton Agar by Kirby-Bauer method ${ }^{[18]}$ using the following antibiotic discs, Imipenem, Piperacillin/Tazobactam, Cefoperazone/ sulbactam, Ceftazidime, Augmentin, Amikacin, Nitrofuration, Cefipime, Ceftriaxone, Gentamicin, Nalidixic acid, Levofloxacin, Ciprofloxacin, Cotrimoxazole, Vancomycin, Novobiocin, Penicillin, Erythromycin and Tetracycline accordingly.

\section{Statistical analysis}

The data were entered and analysed using Statistical Package for Social Sciences SPSS software version 21.0. P - Value $<0.05$ was considered statistically significant.

\section{Results and Discussion}

Out of total collected 351 successful samples 176 females and 175 males and were in the study group of 1 to above 60 years old. There were higher numbers of samples collected from the extreme of ages 1-9 years both males/females $(23.5 \%) /(20.5 \%)$ and above 60 years both males/females $(20.6 \%) /(24.5)$. In age groups of 20-29 years and above 60 years there were higher numbers of negative samples of males and females respectively showing no growth on culture plates. That could be due to indiscriminate consumption of non-prescribed antibiotics by the peoples whenever difficulty in urination was noticed. UTIs were higher in numbers of females than males in age group of 1-9 years because of continuous wetting and due to difficulty in keeping dry under wears and may be due to short distance between vagina and anus which make easy excess of pathogens in female urinary tract. The male positive samples above 60 years old showed high risk of infections due to bladder outlet obstruction in older men there might be bacterial prostatitis and non-bacterial prostatitis. For the age group 30-39 years again females showed higher risk of infections than males because younger females represented complication of sexually transmitted urethritis. However, in 10-19 years age groups both males and females samples there were a slight difference of positive and negative samples. Both the extremes of age groups have risk of UTIs infections due to low immunity (Table 2).

Out of total 351 collected samples 134 samples showed no growth on culture plates. 217 were positive samples. Pathogenic microbes were isolated from 217 positive samples $(61.8 \%)$ which in the vast majority of cases E. coli (57.2\%) followed by Pseudomonas (16.1\%) and Klebsiella species (9.6\%) were among the most frequent uropathogen bacteria. That was similar to other studies where it was the most frequent pathogen causing UTI as studied by Mehar where $62.6 \%$ cultures grew E. coli 16 and $66 \%$ E. coli studied by Naeem in Islamabad ${ }^{17}$.

Those results were also similar with a study conducted by Dilnawaz in 2005 in India which reflects that first two common organisms were E. coli and Klebsiella pneumoniae 18; but in this study first two common organisms were E. coli and Pseudomonas sps. In our study most of cases of UTI were caused by gram negative organisms $(91.1 \%)$, in which female case prevalence was high, similar to other studies (Table 3).

Consequently higher prevalence of gram negative organisms might be due to fecal contamination, the predilection of the organisms from the toilets and the shortness of the female urethra in females. That prevalence however was also reported in 
earlier works by Smith in Australia. ${ }^{[19]}$ There was also a possible link between the prevalence of UTI among population and the level of personal hygiene or the state of toilet facilities. Sexual activity was another feature that predisposes population to UTI. For example Staphylococcus aureus (4.6\%) and
CONS which was a member of skin flora might stay on the skin and get transmitted during sexual intercourse. On examination of demographic state of the cases by age, it was observed that both the extremes of age groups have risk of UTIs.

Table.1 Showing age and gender wise distribution of study participants

\begin{tabular}{|c|c|c|c|}
\hline $\begin{array}{c}\text { Age groups } \\
\text { (years) }\end{array}$ & $\begin{array}{c}\text { Males } \\
\text { No. (Percentage) }\end{array}$ & $\begin{array}{c}\text { Females } \\
\text { No. (Percentage) }\end{array}$ & No. (Percentage) \\
\hline $\mathbf{1 - 9}$ & $41(23.5)$ & $36(20.5)$ & $77(22.0)$ \\
\hline $\mathbf{1 0 - 1 9}$ & $30(17.1)$ & $22(12.5)$ & $52(14.8)$ \\
\hline $\mathbf{2 0 - 2 9}$ & $31(17.7)$ & $30(17.0)$ & $61(17.4)$ \\
\hline $\mathbf{3 0 - 3 9}$ & $10(05.7)$ & $20(11.4)$ & $30(08.5)$ \\
\hline $\mathbf{4 0 - 4 9}$ & $10(05.7)$ & $10(05.6)$ & $20(05.7)$ \\
\hline $\mathbf{5 0 - 5 9}$ & $17(09.7)$ & $15(08.5)$ & $32(09.1)$ \\
\hline$>\mathbf{6 0}$ & $36(20.6)$ & $43(24.5)$ & $79(22.5)$ \\
\hline Total & $175(100)$ & $176(100)$ & $351(100)$ \\
\hline
\end{tabular}

Table.2 Showing age and gender wise distribution of positive and negative samples of study participants

\begin{tabular}{|c|c|c|c|c|}
\hline $\begin{array}{c}\text { Age groups } \\
\text { (years) }\end{array}$ & $\begin{array}{c}\text { Positive samples of } \\
\text { Males No. }(\% \text { age })\end{array}$ & $\begin{array}{c}\text { Negative samples of } \\
\text { Males No. }(\% \text { age })\end{array}$ & $\begin{array}{c}\text { Positive samples of } \\
\text { Females No. }(\% \text { age) }\end{array}$ & $\begin{array}{c}\text { Negative samples of } \\
\text { Females No. }(\% \text { age })\end{array}$ \\
\hline $\mathbf{1 - 9}$ & $22(22.4)$ & $19(24.7)$ & $32(26.9)$ & $04(07.0)$ \\
\hline $\mathbf{1 0 - 1 9}$ & $15(15.3)$ & $15(19.5)$ & $10(08.4)$ & $12(21.0)$ \\
\hline $\mathbf{2 0 - 2 9}$ & $07(07.2)$ & $24(31.2)$ & $20(16.8)$ & $10(17.6)$ \\
\hline $\mathbf{3 0 - 3 9}$ & $09(09.2)$ & $01(01.3)$ & $19(16.0)$ & $01(01.8)$ \\
\hline $\mathbf{4 0 - 4 9}$ & $08(08.2)$ & $02(02.5)$ & $04(03.3)$ & $06(10.5)$ \\
\hline $\mathbf{5 0 - 5 9}$ & $16(16.3)$ & $01(01.3)$ & $08(06.7)$ & $07(12.3)$ \\
\hline$>\mathbf{6 0}$ & $21(21.4)$ & $15(19.5)$ & $26(21.9)$ & $17(29.8)$ \\
\hline Total & $98(100)$ & $77(100)$ & $119(100)$ & $57(100)$ \\
\hline
\end{tabular}

Table.3 Showing percentage of isolation of microbes from UTIs

\begin{tabular}{|l|c|c|c|}
\hline \multicolumn{1}{|c|}{ Organisms Isolated } & Males (\%) & Females (\%) & Total (\%) \\
\hline E. coli & $48(57.8)$ & $76(56.8)$ & $124(57.2)$ \\
\hline Pseudomonas Sps & $14(16.9)$ & $21(15.7)$ & $35(16.1)$ \\
\hline Klebsiella Sps & $10(12.0)$ & $11(8.2)$ & $21(9.7)$ \\
\hline Proteus Sps & $04(4.8)$ & $06(4.5)$ & $10(4.6)$ \\
\hline Citrobacter Sps & $03(3.6)$ & $06(4.5)$ & $09(4.1)$ \\
\hline Staphylococcus aureus & $03(3.6)$ & $07(5.2)$ & $10(4.6)$ \\
\hline Coagulase negative Staphylococcus & $01(1.2)$ & $04(2.9)$ & $05(2.3)$ \\
\hline Candida Sps Total & $00(0.0)$ & $03(2.2)$ & $03(1.4)$ \\
\hline \multicolumn{1}{|c|}{ Ton } & 83 & 134 & $217(100)$ \\
\hline
\end{tabular}


Table.4 Percentage susceptibility of Gram negative isolates of UTIs

\begin{tabular}{|l|c|c|}
\hline \multicolumn{1}{|c|}{ Antibiotics } & Susceptibility & Percentage \\
\hline Imipenem & $198 / 199$ & $99.4 \%$ \\
\hline Piperacillin/Tazobactam & $170 / 199$ & $85.4 \%$ \\
\hline Cefoperazone/ Sulbactam & $128 / 199$ & $64.4 \%$ \\
\hline Ceftazidime & $112 / 199$ & $56.2 \%$ \\
\hline Augmentin & $107 / 199$ & $53.7 \%$ \\
\hline Amikacin & $105 / 199$ & $52.7 \%$ \\
\hline Nitrofurantion & $101 / 199$ & $50.7 \%$ \\
\hline Cefipime & $100 / 199$ & $50.2 \%$ \\
\hline Ceftriaxone & $95 / 199$ & $47.7 \%$ \\
\hline Gentamicin & $90 / 199$ & $45.2 \%$ \\
\hline Nalidixic acid & $75 / 199$ & $37.6 \%$ \\
\hline Levofloxacin & $70 / 199$ & $35.1 \%$ \\
\hline Ciprofloxacin & $48 / 199$ & $24.1 \%$ \\
\hline Cotrimoxazole & $28 / 199$ & $14.1 \%$ \\
\hline
\end{tabular}

Table.5 Percentage susceptibility of Gram positive isolates of UTIs

\begin{tabular}{|l|c|c|}
\hline \multicolumn{1}{|c|}{ Antibiotics } & Susceptibility & Percentage \\
\hline Vancomycin & $18 / 18$ & $100 \%$ \\
\hline Augmentin & $14 / 18$ & $77.7 \%$ \\
\hline Nitrofurantion & $13 / 18$ & $72.2 \%$ \\
\hline Novobiocin & $13 / 18$ & $72.2 \%$ \\
\hline Tetracycline & $12 / 18$ & $66.6 \%$ \\
\hline Erythromycin & $12 / 18$ & $66.6 \%$ \\
\hline Ciprofloxacin & $12 / 18$ & $66.6 \%$ \\
\hline Nalidixic acid & $12 / 18$ & $66.6 \%$ \\
\hline Gentamicin & $12 / 18$ & $66.6 \%$ \\
\hline Cefotaxime & $11 / 18$ & $61.1 \%$ \\
\hline Cefoperazone & $11 / 18$ & $61.1 \%$ \\
\hline Penicillin & $4 / 18$ & $22.2 \%$ \\
\hline
\end{tabular}

Antibiogram in our study showed that Imipenem and Piperacillin/Tazobactam were most susceptible drugs for UTI infection while Ciprofloxacin and Cotrimoxazole showed least susceptibility for the isolates, which is alarming because these drugs are used as empirical treatment for UTI (Table 4).

Vancomycin and Augmentin were most effective antibiotics for isolated gram positive bacteria, while Penicillin is most resistant drug for gram positive bacteria. Those antibiotics are still effective for treatment of urinary tract infections. The majority of antibiotics tested according to tables 4 and 5 resistance of uropathogens against majority of commonly used antibiotics increased. The implication of that was the possibility of easy access causing self-medication, misuse and abuse, leading to the development of resistance. The selection of antibiotic against any urinary tract pathogen depends on the 
antibiotic resistance pattern, its pharmacokinetic properties, dose quantity and timings, its effect on gastrointestinal tract and vaginal flora allergies and adverse effects caused by that drug. ${ }^{[20]}$ Antimicrobial resistance was a big problem cause of great concern throughout the world. Knowledge of the antibacterial resistance among uropathogens was essential to provide appropriate cost effective therapy.

In our study $E$. coli showed to be the most predominant uropathogen which shows that there is an increasing need for selection of appropriate and effective antibiotics, as the antibiotic resistance patterns are increasing against microorganisms causing UTI. Unsystematic recommendation and use of antibiotics should be checked in both the public and hospital setting by increasing public awareness on rational antibiotics use as well as taking on stern national and local antibiotic policy to standardize the recommendation, sale and use of antibiotics. Appropriate use of empirical antibiotics based on the bacterial susceptibility of that particular area is of utmost importance because most of the drugs are gaining resistance.

\section{Acknowledgements}

I am very thankful to all peoples who supported my study and all departments of Raichur Institute of Medical Sciences and Teaching Hospital.

\section{References}

1. Tice, A. D. (1999). Short course therapy of acute cystitis: a brief review of therapeutic strategies. Journal of Antimicrobial Chemotherapy 43, 85-93.

2. Clarridge, J. E., Johnson, J. R. \& Pezzlo, M. T. (1998). Cumitech 2B, Laboratory Diagnosis of Urinary Tract Infections,
(Weissfeld, A. S., Ed.). American Society for Microbiology, Washington, DC.

3. Sussman, M. (1998). Urinary tract infections. In Topley \& Wilson's Microbiology and Microbial Infections, 9th edn, (Collier, L., Balows, A. \& Sussman, M., Eds), pp. 601-21. Arnold, London.

4. Cunningham FG, Gant NF, Leveno KJ, Gilstrap LC III, Hauth JC, Wenstrom KD. Renal and Urinary Tract Disorders. In: Andrea Seils, Noujaim SR, Daris K, editors. Williams Obstetrics. 21st ed. New York: McGraw- Hill Medical Publishing Division. 2001;1251-1272.

5. Karlowsky JA, Kelly LJ, Thornsberry C, Jones ME, Sahm D. Trends in antimicrobial resistance among urinary tract infection isolates of Escherichia coli from female outpatients in the United States. Antimicrob Agents Chemother 2002;46:2540-5.

6. Khan SW, Ahmed A. Uropathogens and their susceptibility pattern: a retrospective analysis. J Pak Med Assoc 2001; 51(2): 98-100.

7. Farrell DJ, Morrissey I, De Rubeis D et al. A UK multicentre study of the antimicrobial susceptibility of bacterial pathogens causing urinary tract infection. J Infect 2003; 46(2):94-100.

8. Hasan AS, Nair D, Kaur $J$ et al. Resistance patterns of urinary isolates in a tertiary Indian hospital. J Ayub Med Coll Abbottabad 2007; 19(1):39-41.

9. Farajnia S, Alikhani MY, Ghotaslou R et al. Causative agents and antimicrobial susceptibilities of urinary tract infections in the northwest of Iran. Int J Infect Dis 2009; 13(2):140-144.

10. Jones RN, Kugler KC, Pfaller MA, Winokur PL. Characteristics of pathogens causing UTIs in hospitals in North America: Results from SENTRY Antimicrobial Surveillance Program 1997; 
Diagn Microbiol Infect Dis 1999; 15. Smith PJ, Morris AJ, Reller LB. 35(1):55-63.

11. Akortha EE, Ibadin OK. Incidence and antibiotic susceptibility pattern of Staphylococcus aureus amongst patients with urinary tract infection (UTI) in UBTH Benin City, Nigeria. African J Biotech 2008; 7(11):1637- 1640.

12. Mathai D, Jones RN, Pfaller MA. Epidemiology and frequency of resistance among pathogens causing urinary tract infection in 1,510 hospitalized patients: a report from the SENTRY Antimicrobial Surveillance Program (North America). Diag Microbiol Infect Dis 2001; 40:129136.

13. Wise, R., Hart, T., Cars, O., Streulens, M., Helmuth, R. \& Huovinen, P. (1998). Antimicrobial resistance is a major threat to public health. British Medical Journal 317, 609-10.

14. Forbes BA, Sahm DF, Weissfeld AS. Bailey and Scott's Diagnostic microbiology, Mosby Elsevier, (12), 2007, 842-855. Predicting Urine Culture Results by Dipstick Testing and Phase Contrast Microscopy. Pathol, 35 (2), 2003, 161.

16. Cheesbrough Moneca. District Laboratory Practice in Tropical Countries, 2 (2), 2005, 105-114.

17. Fawole E, Oso. An introduction to laboratory Manual of Microbiology. University printing press Ibadan Nigeria, (31), 1998, 23-34.

18. WHO SEARO, Guidelines on standard operating procedures for Microbiologyantimicrobial susceptibility testing. 2006.

19. Smith PJ, Morris AJ, Reller LB. Predicting Urine Culture Results by Dipstick Testing and Phase Contrast Microscopy. Pathol, 35 (2), 2003, 161.

20. Zareef S, Zafar H, Izhar K, Dodhy, Ehsan $\mathrm{M}$, Hayat A. The culture and sensitivity pattern of uropathogens detected at Benazir Bhutto hospital. Ann. Pak. Inst. Med. Sci., (5), 2009, 121-12.

\section{How to cite this article:}

Venkatesh Naik, R., Basavaraj V. Peerapur and Sandhya, P. 2017. A Retrospective Study of the Culture and Sensitivity Pattern of Urinary Tract Infection Causing Organisms at RIMS Teaching Hospital, Raichur. Int.J.Curr.Microbiol.App.Sci. 6(10): 1530-1536. doi: https://doi.org/10.20546/ijcmas.2017.610.183 